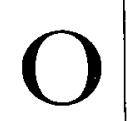

n 15 February of this year, shortly after the number of people Dr. Jack Kevorkian had helped to commit suicide swelled to fifteen, the Michigan legislature passed a law, effective that very day, making assisted suicide a felony punishable by up to four years in prison. The law, which is automatically repealed six months after a newly established commission on death and dying recommends permanent legislation, prohibits anyone with knowledge that another person intends to commit suicide from "intentionally providing the physical means" by which that other person does so or from "intentionally participat[ing] in a physical act" by which she does so. ${ }^{1}$

A two-thirds majority of each house was needed to give the new Michigan law immediate effect, but that requirement was easily met. The governor applauded the legislature and signed the law the same day. But this is not the end of the story. A week later, the American Civil Liberties Union of Michigan brought a lawsuit on behalf of two cancer patients and several health care professionals who specialize in the care of the terminally ill, attacking the law's constitutionality. The essence of the challenge is that insofar as the law prohibits a health professional, family member, or friend from assisting a competent, terminally ill person who wishes to hasten her death, the law violates the due process clauses of the state and federal constitutions and the "Right to Privacy Guarantee" of the state constitution.

If the Michigan Supreme Court overturns the prohibition against assisted suicide on state constitutional grounds, this particular lawsuit will come to an end. If, however, as I think likely, the state supreme court upholds the prohibition, the U.S. Supreme Court may decide to review the matter. Since approximately twenty-five states expressly prohibit

Yale Kamisar is Clarence Darrow Distinguished University Professor at The University of Michigan Law School, Ann Arbor.

Yale Kamisar, "Are Laws against Assisted Suicide Unconstitutional?" Hastings Center Report 23, no.3 (1993): 32-41.

\title{
Are Laws against Assisted Suicide Unconstitutional?
}

\author{
by Yale Kamisar
}

\begin{abstract}
The Supreme Court, reluctant to find constitutional rights in areas marked by divisive social and legal debate, is not likely to constitutionalize a right to assisted suicide. The Court should cleave to the tradition of discouraging suicide and criminalizing its assistance.
\end{abstract}

assisted suicide by statute and another ten or twelve make some types of assisted suicide a form of murder or manslaughter, ${ }^{2}$ the Supreme Court is likely to address the question in some case from some state, whether Michigan or another, in the near future.

In this article I shall only discuss federal constitutional arguments for invalidating laws against suicide. I shall also discuss various reasons why I believe these arguments will (and should) fail.

\section{Is There a "Right" to Commit Suicide?}

So far as I know, no state law makes either suicide or attempted suicide a crime. Why is this so? And what follows from this?

According to Dan Brock, who supports both physician-assisted suicide and voluntary active euthanasia, the fact "that suicide or attempted suicide is no longer a criminal offense in virtually all states indicates an acceptance of individual self-determination in the taking of one's own life analogous to that required for voluntary active euthanasia." I am not sure what Professor Brock means by "acceptance"; it is an ambiguous term. In context, however, he seems to be viewing the fact that we no longer punish suicide or attempted suicide as approval of these acts or at least as recognition that self-determination or autonomy extends this far-namely, that taking one's life is a valid application or aspect of individual self-determination. If this is what he means, he is quite mistaken.

As the most comprehensive and most heavily documented law review article ever written on the subject makes clear, abolition of such "punishments" as ignominious burial for suicide and then the decriminalization of both suicide and attempted suicide did not come about because suicide was deemed a "human right" or even because it was no longer considered reprehensible. These changes occurred, rather, because punishment was seen as unfair to innocent relatives of the suicide and because those who committed or attempted to commit the act were thought to be prompted by mental illness.

Some of this thinking is reflected in the comments to the American Law Institute's Model Penal Code. The code does criminalize aiding or soliciting another to commit suicide, but not suicide itself or attempted suicide. Why not? "There is a certain moral extravagance in imposing criminal punishment on a person who has sought his own self-destruction ... and who more properly requires medical or psychiatric attention." 
Sympathy and pity for the individual who attempts suicide "emphatically did not mean approval of the act." From colonial days through at least the $1970 \mathrm{~s}$, "the predominant attitude of society and the law has been one of opposition to suicide."

The Model Penal Code's judgment that "there is no form of criminal punishment that is acceptable for a completed suicide and that criminal punishment is singularly inefficacious to deter attempts to commit suicide" (p. 94) does not mean that there is a "right" to commit the act. As Leon Kass has pointed out, the capacity to take one's life-"I have inclination, means, reasons, opportunity, and you cannot stop me, and it is not against the law"-does not establish the right to do so. Nor does it mean that one has "a justified claim against others that they act in a fitting manner." As a practical matter, at least so long as they do not resort to physical violence, parents are "free" to treat their children unkindly, even cruelly. But few, if any, would say that a mother or father has a "right" to be a bad parent.

Society can do something about those who aid another to commit suicide-and it has. Throughout our history we have directed the force of the criminal law against aiding or assisting suicide. The commentary to the Model Penal Code notes that the fact that penal sanctions will not deter the suicide itself

does not mean that the criminal law is equally powerless to influence the behavior of those who would aid or induce another to take his own life. Moreover, in principle it would seem that the interests in the sanctity of life that are represented by the criminal homicide laws are threatened by one who expresses a willingness to participate in taking the life of another, even though the act may be accomplished with the consent, or at the request, of the suicide victim (p. 100).

Another word about the Model Penal Code. In the memorable dictum of Oliver Wendell Holmes, "It is revolting to have no better reason for a rule of law than that so it was laid down in the time of Henry IV." The quickest way to refute the belief not a few may hold that the reason for the criminal prohibition against assisted suicide falls into Holmes's category is to point to the position taken by the code. Its final "Official Draft" was the product of many years of research, deliberation, drafting, and revising by the most eminent criminal law scholars of the $1950 \mathrm{~s}$ and $60 \mathrm{~s}$, led by Herbert Wechsler of Columbia University and Louis $B$. Schwartz of the University of Pennsylvania. To quote a leading scholar of the present day, the code "has become the principal text in criminal law teaching, the point of departure for criminal law scholarship, and the greatest single influence on the many new state codes that have followed in its wake."

The Model Code's reporters considered the argument that the criminality of assisted suicide should turn upon "the presence of a selfish motive" (a position supported by one of its special consultants, England's Glanville Williams), but concluded that "the wiser course is to maintain the prohibition and rely on mitigation in the sentence when the ground for it appears." ${ }^{, 10}$ With the stimulus of the Model Code, in the next decade and a half, eight states passed new laws specifically prohibiting assisted suicide and eleven other jurisdictions revised their existing statutes. ${ }^{11}$

\section{Does the "Right to Die" Include the Right to Assisted Suicide?}

As a rallying cry, the "right to die" is hard to beat. But it is much easier to chant a slogan than to apply it to specific situations. Most would consider the refusal of lifesaving medical procedures under certain circumstances (such as terminal illness and severe pain) an apt illustration of the "right to die." But the term has also been used loosely and broadly to embrace such claims as the right to another's help in committing suicide and the right to authorize another to engage in active euthanasia.

Many proponents of the "right to die" are quick to point out that the "sanctity of life" is not an absolute or unqualified value (and they are right), but they are slow to realize that the same is true of the "right to die."
There is no absolute or general "right to die." The only right or liberty that the Karen Ann Quinlan case and subsequent so-called "right to die" rulings have established is the right under certain circumstances to be disconnected from artificial life support systems or, as many have called it, the right to die a natural death. And the new Michigan ban against assisted suicide recognizes that right by explicitly excluding "withholding or withdrawing medical treatment" from its coverage. (It also exempts "prescribing, dispensing or administering" medication or treatment designed "to relieve pain or discomfort and not to cause death, even if the medication or procedure may hasten or increase the risk of death.")

In the 1970s, the Quinlan case brought the "right to die" issue to national prominence and set the tone for the developments in law and bioethics that followed. But the Quinlan court specifically distinguished between committing or assisting in a suicide and what it called "the ending of artificial life support systems"-the only issue presented. ${ }^{12}$

As one of the leading commentators in this field, Rutgers Law School's Norman Cantor, recently observed: "The assertion that rejection of life-saving medical treatment by competent patients constitutes suicide has been uniformly rejected-usually based on a distinction between letting nature take its course and initiating external deathcausing agents."13

The distinction between euthanasia (or, I believe, assisted suicide as well) and "letting die" is elucidated in The Troubled Dream of Life, a soon-to-bepublished book by Daniel Callahan. "As a reality of nature," observes Dr. Callahan, "killing and letting die are causally different. . . . There must be an underlying fatal pathology if allowing to die is even possible. Killing, by contrast, provides its own fatal pathology. Nothing but the action of the doctor giving the lethal injection is necessary to bring about death."14

Since the reasons usually advanced to distinguish persons terminating life support from "ordinary" suicides do not strike Jeb Rubenfeld as "altogether persuasive" (nor me either), Professor Rubenfeld has suggested 
another answer to "this painful riddle":

For right-to-die patients, being forced to live is in fact to be forced into a particular, all-consuming, totally dependent, and indeed rigidly standardized life: the life of one confined to a hospital bed, attached to medical machinery, and tended to by medical professionals. It is a life almost totally occupied....

In contrast, the "ordinary" suicide suffers no such total occupation of his life or affirmative use of his body. An avenue of escape is foreclosed to him [but the prohibition of suicide] does not, as a rule, direct lives into a particular, narrowly confined course. ${ }^{15}$

This is a thoughtful answer and an interesting one. But still more interesting, I believe, is that this commentator, who has a strong commitment to the right to privacy and who usually interprets it expansively, evidently feels a deep need (as I do) to draw a boundary somehow between the withholding or withdrawal of life-sustaining medical treatment and what he calls " ordinary' suicide."

The one "right to die" case that rivals Quinlan for prominence is the 1990 Nancy Beth Cruzan decision, the only case on death, dying, and the "right of privacy" ever decided by the U.S. Supreme Court. As did Quinlan, the Cruzan case involved the right to end artificial life support, and it too provides no comfort to proponents of a constitutional right to assisted suicide.

The Cruzan Court sustained a state's power to keep alive, over her family's objections, an incompetent patient who had not left clear instructions for ending life-sustaining treatment. In the course of rejecting the efforts of Ms. Cruzan's parents to terminate her artificial feeding, Chief Justice Rehnquist, who spoke for five members of the Court, pointed out that a state has an undeniable interest in the protection and preservation of human life-even the life of a person in a persistent vegetative state. The chief justice supported this assertion by noting that "the majority of states in this country have laws imposing criminal penalties on one who assists another to commit suicide."16

If a majority of the Supreme Court meant to suggest that laws against assisted suicide are constitutionally suspect, it chose a strange way of doing so.

The chief justice "assumed for purposes of this case" that a competent person does have "a constitutionally protected right to refuse lifesaving hydration and nutrition." But he declined to characterize it as a "fundamental right," a designation that requires a state to offer a compelling justification for a right's restriction (a test the state can rarely satisfy). He called the right instead a Fourteenth Amendment liberty interest: "Although many state courts have held that a right to refuse treatment is encompassed by a generalized constitutional right of privacy, we have never so held. We believe this issue is more properly analyzed in terms of a Fourteenth Amendment liberty interest."

"By avoiding 'fundamental right' language," comments John Robertson, "the Court may implicitly allow states to restrict the 'liberty interest' upon a lesser showing of need than it would require if that interest were characterized as a fundamental right." Perhaps "any reasonable state interest" would justify state interference with that liberty "or at least one which did not impose an 'undue burden.",17

Of course, the Court did not suggest that one has even so much as "a Fourteenth Amendment liberty interest" in assisted suicide, and I cannot believe that it will do so in the foreseeable future. If I am right, a Court assessing the constitutionality of a ban against assisted suicide would give great deference to the state legislature; if it furthered some coherent conception of the public good, that would probably suffice.

The Cruzan case is hardly the Court's last word on death, dying, termination of life support, assisted suicide, and euthanasia. The principles lurking in this area will be brought into sharper focus only by new prodding of the facts of new cases and by taking a fresh look, each time, at the overall problem. If Cruzan demonstrates anything, however, I think it signals the reluctance of the High Court to "constitutionalize" an area marked by divisive social and legal debate and its inclination to defer instead to the states' judgments in this difficult field. ${ }^{18} \mathrm{~A}$ Court that refused to "constitutionalize" a "right to die" broad enough to uphold the claims of the Cruzan family is hardly likely to "constitutionalize" a right to assisted suicide.

\section{Justice Scalia's Opinion}

We should not forget that there was one justice in the Cruzan case who did equate the termination of life support with "ordinary" suicide-Antonin Scalia. Although his lone concurring opinion was more or less ignored by the other justices, it should not go unnoticed.

Justice Scalia maintained that for constitutional purposes "there is nothing distinctive about accepting death through the refusal of 'medical treatment,' as opposed to accepting it through the refusal of [natural] food, or through the failure to shut off the engine and get out of the car after parking in one's garage after work." As he viewed the case, the request of Nancy Cruzan's parents to terminate their daughter's artificial feeding and hydration was, in effect, the assertion of a "right to suicide."

But Justice Scalia is well aware that "on the question you ask depends the answer you get." A principal reason, surely, why he framed the question the way he did was his confidence that there was no way a majority of the Court would recognize a constitutional right to commit suicide. And nothing any of the other eight justices said suggests that Scalia's confidence was unfounded.

In fact, the other justices did not say anything about a "right to suicide." None of them disputed Scalia's point "that American law has always accorded the State the power to prevent, by force if necessary, suicide." Nor did any of them disagree that "there is no significant support for the claim that a right to suicide is so rooted in our tradition that it may be deemed 'fundamental' or 'implicit in the concept of ordered liberty.'” As Louis Seidman remarks, the Cruzan dissenters "carefully avoid any claim 
that state suicide statutes are unconstitutional-a reticence that Justice Scalia powerfully exploits in his concurring opinion." ${ }^{19}$ This is a reticence, I might add, that does not bode well for proponents of a constitutional right to assisted suicide.

Although none of Justice Scalia's colleagues responded in so many words to his argument that the termination of lifesaving medical treatment constitutes suicide, they responded nevertheless. They all framed the question in terms of a right to refuse or to be free from "unwanted medical treatment" or, more specifically, "unwanted artificial nutrition and hydration."

As a matter of logic, I think there is a good deal to be said for analogizing a patient's termination of life-sustaining medical treatment to "ordinary" suicide. But law is not entirely a syllogism.

It may be helpful to view the Cruzan case as involving two competing traditions. ${ }^{20}$ One is the common-law right to refuse medical treatment, even lifesaving surgery-in the language of the Court, "the logical corollary of the doctrine of informed consent," a doctrine "firmly entrenched in American tort law," is the right not to consent, that is, to reject treatment. The other tradition, which has continued to exist alongside the first one, is the antisuicide tradition, as evidenced by society's discouragement of suicide and attempted suicide and by the many criminal laws against assisted suicide.

In Cruzan a majority, perhaps as many as eight justices, evidently decided that the termination of artificial nutrition and hydration was more consistent with the rationale of the cases upholding the right to refuse treatment; so far as we can tell, only Justice Scalia believed it implicated the concerns underlying the antisuicide tradition.

\section{Assisted Suicide vs. Active \\ Voluntary Euthanasia}

The line between doctor-assisted suicide and physician-administered voluntary euthanasia is a fine one that is often blurred. Voluntary euthanasia "has been variously described as 'assisted suicide' or 'within the knife's edge between suicide and murder," and suicide has sometimes been called "self-administered euthanasia." ${ }^{21}$

Doctor-assisted suicide is not quite active voluntary euthanasia for, unlike euthanasia, the final act, the one that brings on death, is performed by "it puts the physician in a very powerful position," whereas in the case of doctor-assisted suicide "the balance of power between doctor and patient is more nearly equal." 23

I find this reasoning more conclusory than explanatory. Dr. Quill would require many safeguards for

\section{Voluntary euthanasia would receive very serious consid- eration once assisted suicide were legalized or as soon as the Supreme Court established a constitutional right to commit "rational" suicide.}

the patient herself, not her doctor. But suppose that a person is unable to swallow the barbiturates that will bring about death or lacks the physical capacity to trigger a suicide machine? If the right to control the time and manner of one's death-the right to shape one's death in the most humane and dignified manner one chooses-is well founded, how can it be denied to someone simply because she is unable to perform the final act by herself? Although there is a "mechanical" distinction between assisted suicide and euthanasia, is it not a distinction without a difference?

Yes, answered the late Joseph Fletcher, who advocated active euthanasia for some fifty years. As he viewed the matter, "It is impossible to separate [active voluntary euthanasia] from suicide; it is indeed, a form of suicide" and the case for active voluntary euthanasia "depends upon the case for the righteousness of suicide." James Rachels, author of a famous assault on the distinction between "killing" and "letting die," similarly maintains that "the permissibility of euthanasia follows from the permissibility of suicide - a result that probably will not surprise any thoughtful person."22

That may be, but it is a result some thoughtful persons have strongly resisted. Thus, in his new book, Dr. Timothy Quill comes out in favor of physician-assisted suicide but balks at active voluntary euthanasia. He does not support euthanasia because of the "potential for abuse" and because doctor-assisted suicide (the patient must freely, clearly, and repeatedly ask to die; her judgment must not be distorted; the physician must make sure that the patient's suffering and request are not the product of inadequate comfort care). If, as he believes, these safeguards would greatly reduce the risk of abuse and render the balance of power between doctor and patient relatively equal, why would they not achieve the same results for voluntary euthanasia? Conversely, if, even when all the safeguards Quill proposes are in place, it would still be imprudent to legalize active voluntary euthanasia, why is it safe to sanction assisted suicide?

Quill recognizes that "access to medical care in the United States is too inequitable and many doctorpatient relationships too impersonal to tolerate the risks of condoning active voluntary euthanasia" (p. 160). But why can't the very same thing be said about tolerating the risks of condoning assisted suicide?

I find it difficult to avoid the conclusion that Dr. Quill's position is colored by the fact, as he notes, that "unlike assisted suicide, where the legal implications have yet to be fully clarified, euthanasia is illegal in all states in the United States and likely to be vigorously prosecuted" (p. 142). Dr. Quill and I disagree about a number of things. But I venture to say we are in agreement on one: the uniform ban against active euthanasia is not going to be struck down on the ground that it violates the "right to 
die." Therefore, a proponent of the right to assisted suicide is understandably likely to put as much distance as possible between that concept and euthanasia.

Although he would not legalize voluntary euthanasia, at least not at this time, Dr. Quill does consider it "an area worthy of our serious consideration, since it would allow patients who have exhausted all other reasonable options to choose death rather than continue suffering" ( $p$. 143). I make bold to say that voluntary euthanasia would receive very serious consideration once assisted suicide were legalized or as soon as the Supreme Court established a constitutional right to commit "rational" suicide.

Although I am opposed to both assisted suicide and voluntary euthanasia, I find the position of Professor Brock (who supports both practices) more coherent and more principled than Dr. Quill's:

In both [assisted suicide and voluntary euthanasia], the choice rests fully with the patient. In both [cases] the patient acts last in the sense of the right to change his or her mind until the point at which the lethal process becomes irreversible....

If there is no significant, intrinsic moral difference between the two, it is difficult to see why public or legal policy should permit one but not the other; worries about abuse or about giving anyone dominion over the lives of others apply equally well to either. ${ }^{24}$

The fine distinction between assisted suicide and voluntary euthanasia was blurred by the hard-fought campaigns in Washington (1991) and California (1992) to legalize "aidin-dying," a label covering both assisted suicide and voluntary euthanasia. I watched both campaigns very closely and came away with the distinct impression that few, if any, understood the distinction between the two practices, paid any attention to it, or cared one whit about it.

The inability of the media, the public, and even members of the medical profession to grasp this fine distinction is powerfully illustrated by a two-hour presentation, "Choosing
Death," a program shown on most PBS stations about the time this article was going to press.

Although the program was billed as a "debate about euthanasia," it soon became clear that it was a debate about assisted suicide as well. Very early in the program the moderator, Roger Mudd, announced: "The issue is doctor-assisted suicide and euthanasia." At another point he asked Professor Margaret Battin whether there was any way "other than euthanasia or physician-assisted suicide ... to end suffering." Still later, he asked a physician affiliated with Harlem Hospital "whether you think euthanasia-physician-assisted suicideposes any dangers to America's minorities." 25 And although Dr. Jack Kevorkian has been careful never to practice active voluntary euthanasia (all the people he helped die by suicide performed "the last act" themselves), he appeared in the opening segment.

It is difficult to fault the moderator for treating assisted suicide and voluntary euthanasia interchangeably. After all, none of the physicians or bioethicists who appeared on the program saw the need or, at any rate, took the trouble to draw any distinction between the two concepts. At one point Dr. Howard Brody maintained that "we can find other alternatives that don't require physicianassisted suicide or euthanasia." And at another point Professor Dan Brock pointed out that "we ought to be doing our best to improve all dying patients' care, whatever one's view about assisted suicide, or euthanasia, is." (As mentioned earlier, Professor Brock doesn't see any real distinction between the two concepts. Is this also true of all the others who appeared on the program?)

\section{Can the Right to Assisted Suicide be Confined to the Terminally Ill?}

No doubt the ACLU, in challenging the constitutionality of the Michigan prohibition against assisted suicide, will frame the issue narrowly; it will emphasize that it is only asserting the rights of the terminally ill who may desire death by suicide. But is there any principled way so to limit the right?
Of course, it is good advocacy to frame the issue in terms of the rights of the "dying" or "terminally ill," but what reason (other than those of tactics) can be advanced for this position? If the merciful termination of suffering (or termination of an unendurable existence) is the basis for this right, why limit it to those who are terminally ill? As Professor Robert Wennberg has asked:

Why ... should the non-terminal nature of one's suffering exclude one from qualifying or make it more difficult for one to qualify as a fitting subject for suicide? To be sure, the person with a non-terminal illness has longer to live, and should that person choose to commit suicide, he or she would be eliminating a greater span of future existence. ... But [such a] person is also eliminating a proportionately greater quantum of pain and suffering, and if the smaller quantum justifies the elimination of the shorter span of life, then the greater quantum might justify the elimination of the longer span. ${ }^{26}$

Alan Sullivan, who has presented one of the best arguments for a constitutional right to suicide, makes plain that he would not limit such a right to the terminally ill. "Surely," he observes, "under a variety of circumstances life may be unendurable to a reasonable person, even though he does not face the prospect of immediate and painful death."27

It is interesting to note that, although he carefully circumscribes the right to assisted suicide in many respects, Dr. Quill would not limit it to the terminally ill. "The patient must have a condition," Quill tells us, "that is incurable, and associated with severe, unrelenting suffering." Though he anticipates that most people who desire physician-assisted suicide "will be imminently terminal," Quill does "not want to arbitrarily exclude persons with incurable, but not imminently terminal, progressive illnesses such as ALS or multiple sclerosis." ${ }^{28}$ But is it any less arbitrary to exclude the quadriplegic? The victim of a paralytic stroke? The mangled survivor of a road accident? A person afflicted with severe arthritis? 
Why stop there? If a competent person comes to the unhappy conclusion that his existence is unbearable and freely, clearly, and repeatedly requests assisted suicide, why should he be rebuffed because he does not "qualify" under somebody else's standards? Isn't this an arbitrary limitation of self-determination and personal autonomy? "How," asks Daniel Callahan, "can self-determination have any limits? Why are not the person's desires or motives, whatever they be, sufficient?"29

As I understand the position of those advocating a constitutional right to suicide and to assisted suicide, a person who "qualifies" should have the same right to enlist the aid of others to die by suicide as one now has to withhold or withdraw life-sustaining medical treatment. ${ }^{30}$ If so, it is fairly clear that once established, the right to assisted suicide will not be restricted to the terminally ill. For as demonstrated by such decisions as Elizabeth Bouvia, a case involving a young woman with severe cerebral palsy who was not terminally ill, and Larry McAfee, a case involving a quadriplegic who apparently had a long life expectancy, the right to terminate life support has not been so limited. Indeed, the view that life support cannot be stopped unless a patient is terminally ill-a notion that may have originated in pre-Quinlan cases involving the refusal of blood transfusions by Jehovah's Witnesses-is one of the "myths" that Professor Alan Meisel has recently dispelled.

\section{Upholding the Prohibition}

I share the view that before a state can punish its citizens for their actions, "it must do more than assert that the choice they have made is an 'abominable crime not fit to be named among Christians.'" I agree, too, that "the fact that the governing majority in a State has traditionally viewed a particular practice as immoral is not a sufficient reason for upholding a law prohibiting the practice. ${ }^{32}$ But I believe that any state that prohibits assisted suicide can advance justifications for its legislation that go well beyond the law's conformity to religious doctrine or "morality." And
I think these justifications are sufficiently strong to withstand constitutional attack.

I am well aware that the reasons I shall set forth for upholding the new Michigan law and similar laws were not the original reasons for condemning suicide and assisted suicide. But ment or a failure to recognize or adequately to treat depressive illness influenced by prejudice against and stereotypes about elderly people? How likely is it that the social sanctioning of "rational" suicide and assisted suicide will lead to an increase in "irrational" suicide and as-

\section{Any state that prohibits assisted suicide can advance justifications for its legislation that go well beyond the law's conformity to religious doctrine or "morality."}

the new "good reasons" people give for old rules and policies "do influence the development of these policies" and "the 'good reasons' professed by our fathers yesterday are among the real reasons of the life of today." Assigning better reasons for the ban against assisted suicide than the old religious taboo against touching the gates of life and death may be dismissed by some as a process of rationalization, "but the seeking for good reasons ... plays a leading role in the life of civilization." 33

After all, that the criminal law arose to fill the need to regulate self-help and to obviate private vengeance does not render deterrence, incapacitation, and rehabilitation any less of a "real reason" for drafting new criminal codes or revising old ones.

Philosophers have spent much time and effort addressing such questions as, When, if ever, is it "rational" for a person to want to commit suicide? Is there a moral right to commit "rational" suicide? But I think a legislator considering the desirability of a law prohibiting assisted suicide and a judge determining the constitutionality of such a law could ask more relevant questions, such as:

So far as we can tell, how common or rare is "rational" suicide? How often does suicide occur in the absence of a psychiatric disorder? How often do primary care physicians fail to recognize treatable depression in their patients, especially elderly patients? How often is the failure of a primary care physician to take an aggressive approach to pain manage- sisted suicide? In a suicide-permissive society, how often will the "right" to commit suicide and the "right" to enlist the assistance of others in this enterprise be interpreted, especially by the most vulnerable, as the "duty" to do so? In a suicide-permissive society, how often will a burdensome, elderly relative not otherwise desirous of death be "helped along" or pressured or "manipulated" into suicide?

At one point in his argument for a constitutional right to suicide (and for the corollary right to enjoin government agents from taking steps to prevent suicide), Alan Sullivan disposes of a possible objection to his position- "that one suicide might encourage other suicides and ought, for that reason, to be proscribed"-on the ground that "it rests upon psychological assumptions about the suicidal character that are beyond the scope of this essay."

When writing about various subjects I too have put some issues "beyond the scope of this essay." After all, there is only so much time and space to explore a difficult problem (or a cluster of problems). So Mr. Sullivan's decision is understandable, especially when one keeps in mind that suicide is a complicated subject that cuts across many disciplines. But a court assessing the constitutionality of a criminal prohibition against assisted suicide does not have the same luxury. It cannot put psychological assumptions and insights and "psychological autopsy" studies of persons who die by suicide "beyond the scope" of their inquiries. 
Such a court must do more, much more, than simply reason by analogy from the relevant precedents on the books. And such a court must keep in mind that it is doing something quite different from simply judging a debate among philosophers. As Professor Philip Devine has observed:

If philosophers have something to say to the law, so also has the law something to say to philosophers. Attention to the working, or the possible working, of any institution or principle may well give us insight into weaknesses which remain concealed so long as it is posed in sufficiently abstract terms. ${ }^{35}$

\section{The Dangers of Establishing a "Right" to Assisted Suicide}

Suicide is a problem of considerable magnitude. Although it once ranked twenty-second on the list of causes of death in the United States, it now ranks (depending on the particular year) eighth or ninth. Every year there are between 25,000 and 30,000 reported cases of suicide (and the number of cases is probably grossly underreported both because of the social stigma that attaches and because of the possible loss of life insurance benefits). Moreover, it is estimated that every year in this country several hundred thousand people attempt suicide and that about 10 percent of that group go on to kill themselves within a ten-year period. Although suicide occurs at an alarming rate among young people-adolescent suicide in this country increased 300 percent in the twenty years between 1955 and 1975 , while suicides in the fifteen-to-twentyfour age group now constitute about one-fifth of all reported suicides-the highest suicide rates and the greatest number of suicides are found among people over the age of fifty. Indeed, for American white males, from childhood on, the risk of suicide rises linearly with age until the eighth decade of life. Suicides by people over the age of sixty account for about 25 percent of all suicides. ${ }^{36}$

No doubt the higher rate of suicide among the elderly has led advocates of the right to "rational" suicide and to assisted suicide to focus on this age group, especially on elderly people who are terminally ill. But the problem of suicide is a good deal more complicated. Consider the views of Herbert Hendin, a professor of psychiatry and a leading suicidologist, who is opposed to the legalization of doctor-assisted suicide. He concedes that it is sometimes "rational" for a person with a painful terminal illness to wish to end his life. Indeed, "that is precisely why supporters of the 'right to suicide' or 'death control' position are constantly presenting the case of a patient suffering from incurable, painful cancer as the case on which they based their argument." But Dr. Hendin is quick to add:

In reality... such understandable cases form only a small percentage of all suicides, or potential suicides. The majority of suicides confront us with the problem of understanding people whose situation does not seem, from an outsider's viewpoint, hopeless or often even critical. The knowledge that there are more suicides by people who wrongly believe themselves to be suffering from cancer than there are suicides by those who actually have cancer puts the problem in some perspective. ${ }^{37}$

According to suicidologist David Clark, "the major studies all agree in showing that the fraction of suicide victims struggling with terminal illness at the time of their death is in the range of $2 \%$ to $4 \%$." Two-thirds of those who died by suicide when they were in their late sixties, seventies, and eighties "were in relatively good physical health.",38

To ask another relevant question, how often does suicide occur in the absence of a major psychiatric illness? It would not be surprising if the answer to this question were affected by what one thought about the "right" to commit suicide. Some believe that virtually every person who wishes to die by suicide is "mentally ill." Others maintain that such a person is simply called mentally ill so that his behavior may be controlled.

Nevertheless, one cannot ignore the studies that do seem to bear on this question. And when one dips into the relevant literature one dis- covers considerable authority for the view that a suicide rarely occurs in the absence of a major psychiatric disorder.

Two of Timothy Quill's colleagues on the University of Rochester medical faculty, Yeates Conwell and Eric Caine, geriatric psychiatrists who "work with suicidal people every day," warn that "notably lacking" from the debate about rational suicide and physician-assisted suicide is "attention to the effects of psychiatric illness on rational decision making." They point to suicide study findings that " 90 to 100 percent of the victims die while they have a diagnosable psychiatric illness, an observation that is equally true in suicides among the elderly." ${ }^{39}$ A number of other commentators use similarly high figures.

The most commonly cited disorders associated with suicide are depressive affective disorders, also called "depressive illness" or "major depression," a verifiable and diagnosable condition that is usually responsive to prompt treatment. One aspect of major depression, that of hopelessness (which is transient and likely to respond to treatment), appears to be the most probable and frequent source of the impairment that often leads to suicide.

More significant for our purposes, I think, than the prevalence of depressive illness among people who die by suicide is the inability of depressed persons to recognize the severity of their own symptoms and the failure of primary physicians to detect major depression in their patients, especially elderly patients. As Conwell and Caine emphasize:

$[\mathrm{M}]$ any doctors on the front lines, who would be responsible for implementing any policy that allowed assisted suicide, are ill equipped to assess the presence and effect of depressive illness in older patients. In the absence of that sophisticated understanding, the determination of a suicidal patient's "rationality" can be no more than speculation, subject to the influence of personal biases about aging, old age, and the psychological effects of chronic disease. ${ }^{40}$ 
"Ageism"-the prejudices and stereotypes applied to the elderly solely on the basis of their age-may manifest itself in a failure to recognize treatable depression, a refusal to take an aggressive approach to pain management, the view that an elderly person's desire to commit suicide is more "rational" than a younger patient's would be. As sociologist Menno Boldt has observed, "Suicidal persons are succumbing to what they experience as an overpowering and unrelenting coercion in their environment to cease living. This sense of coercion takes many familiar forms: fear, isolation, abuse, uselessness, and so on." 11

Will these pressures intensify in a society that sanctions assisted suicide (and thereby suicide as well)? In a suicide-permissive society, will family members so inclined be more likely to alter or manipulate a sick, elderly person's circumstances (for example, by providing shoddy or even hostile care) so that suicide becomes a reasonable, even an attractive choice?

In a climate in which suicide is the "rational" thing to do, or at least a "reasonable" option, will it become the unreasonable thing not to do? The noble thing to do? ${ }^{42}$ In a suicidepermissive society plagued by shortages of various kinds and a growing population of "nonproductive" people, how likely is it that an old or ill person will be encouraged to spare both herself and her family the agony of a slow decline, even though she would not have considered suicide on her own?

The best discussion of both circumstantial manipulation and ideological manipulation appears in a famous essay by the philosopher Margaret Battin who, ironically, is a proponent of rational suicide. In an all-too-rare display of openminded, balanced scholarship, Professor Battin presents a strong case against her own ultimate position. She conscientiously spells out how acceptance of her views would open the way for both individual and societal manipulation of vulnerable people into choosing death by suicide when they would not otherwise have done so. She concludes, nevertheless, that "on moral grounds we must accept, not reject, the notion of rational suicide."
A state legislature is free to agree with Professor Battin, but must it? Is it constitutionally required to do so? I hardly think so. I believe a legislature is free to give Battin's insights about the dangers of "manipulated suicide" more weight than she herself seems believe, to assisted suicide. As Martin Marty and Ron Hamel have pointed out, "We are not merely a collection of isolated, self-determining individuals." It is unrealistic to think that we can sanction assisted suicide by individuals without having an impact

In a climate in which suicide is the "rational" thing to do, or at least a "reasonable" option, will it become the unreasonable thing not to do?

willing to do; that is one of the risks, if one may call it that, one takes when one produces the kind of high-quality scholarship she does.

Professor Battin may be saying something else: she may be conceding that the dangers of "manipulated suicide" are quite substantial, but they are trumped by one's "fundamental right" to die by suicide. At one point she maintains that we cannot deny "individuals in intolerable and irremediable circumstances their fundamental right to die." Whether there is a "fundamental right" is the question, not the answer. I don't know how those of us who are not religious can get an authoritative ruling on whether morally there is a "fundamental right" to choose death by suicide. But I think I do know that legally there is no such right. As we have seen, a decade after Professor Battin wrote her provocative essay, the Cruzan Court declined to accord the much less controversial liberty to terminate life-sustaining treatment "fundamental right" status.

Although she is painfully aware of "the moral quicksand" into which the notion of rational suicide "threatens to lead us," Professor Battin voices the hope that if we accept that concept "perhaps then we may discover a path around" the quicksand. Perhaps. Perhaps not. In any event, I submit, the Constitution does not prevent a legislature from reaching the conclusion that there is no safe path around.

\section{Some Final Thoughts}

What has been said of voluntary active euthanasia applies as well, I upon "the various communities of which they are a part, and even society as a whole."

I am willing to concede that the line between withholding or withdrawing life-sustaining medical treatment (what many have called passive euthanasia) and "ordinary" suicide and assisted suicide is not a neat, logical line. But what line is? Surely not the line between assisted suicide and voluntary active euthanasia. Nor the line between the right of a terminally ill person to enlist the assistance of others in committing suicide and the right of a quadriplegic to seek similar assistance, or the right of a person who finds her inability even to shift position in her wheelchair intolerable, or the right of a person with a progressive illness.

I cannot believe that any court will recognize a constitutional right to suicide on request. But unless we carry the principle of self-determination or personal autonomy to its logical extreme-assisted suicide by any competent person who clearly and repeatedly requests it for any reason she deems appropriate-we have to find a "stopping point" somewhere along the way. Any such stopping point will be somewhat illogical, somewhat arbitrary. So why not maintain the line we have now?

Albert Alschuler, my counterpart at the University of Chicago Law School, recently declared: "[T]he strongest argument for the actioninaction line is that, despite its indeterminacy and imprecision, we need it. We have no other line, and without it we sense no limits." Professor Alschuler may have overstated the 
case, but not, I think, by very much. Why step across "the historic divide" only to draw another somewhat illogical, somewhat arbitrary line somewhere else? "[I]t is easier to move further down the slope than to climb back up. ${ }^{45}$

In this article I have been focusing on the constitutional dimensions of the right to shape one's death. Thus, I do not have to argue that a state ought not cross the historic divide (although I would); I need only argue that it is not constitutionally compelled to do so. Consider the modern history of our attitudes and beliefs concerning death and dying:

Recent court decisions have rejected many of the distinctions commentators have proposed in earlier discussions about the right to die: not only the distinction between ordinary and extraordinary ... treatment, but also the distinction between actively hastening death by terminating treatment and passively allowing a person to die of a disease, between withholding and withdrawing life-sustaining treatment, and between the termination of artificial feedings and the termination of other forms of life-sustaining treatment. $^{46}$

If, as has well been said, "the history of our activities and beliefs concerning the ethics of death and dying is a history of lost distinctions of former significance, ${ }^{" 17}$ what reason is there to think that that history will come to an end when we sanction assisted suicide for the terminally ill? What reason is there to doubt that in the not-too-distant future the distinction between assisted suicide and voluntary euthanasia or the distinction between the terminally ill and other seriously ill people would become still other "lost distinctions of former significance"?

I can hear the cries of protest: "slippery slope" arguments are a common debating tactic. Yes they areabout as common as the technique of overcoming opposition to a desired goal by proceeding step by step.

\section{Adknowledgments}

I am grateful to my colleagues Larry Kramer and Richard Pildes, and Univer- sity of Michigan law student Marc Spindelman for helpful comments.

\section{References}

1. For a careful, detailed analysis of the Michigan law, see George Annas, "Physician-Assisted Suicide: Michigan's New Law," NEJM (1993) (forthcoming).

2. See Thomas Marzen et al., "Suicide: A Constitutional Right?" Duquesne Law Review 24 (1985): 1-241, at 97-98; George Smith, "All's Well That Ends Well: Toward a Policy of Assisted Rational Suicide or Merely Enlightened Self-Determination?" University of California Davis Law Review 22 (1989): $275-419$, at 290-91. See also Timothy E. Quill, Death and Dignity: Making Choices and Taking Charge (New York: W. W. Norton, 1993), p. 141.

3. Dan Brock, "Voluntary Active Euthanasia," Hastings Center Report 22, no. 2 (1992): 10-22, at 19 (emphasis added).

4. See Marzen et al., "Suicide," pp. 68100.

5. American Law Institute, Model Penal Code and Commentaries, Part I, $\$ 2.10 .5$ at 94 (1985).

6. Marzen et al., "Suicide," pp. 86, 100.

7. See Leon Kass, "Is There a Right to

Die?" Hastings Center Report 23, no. 1 (1993): $34-43$, at $34,35$.

8. Oliver Wendell Holmes, "The Path of the Law," in Collected Legal Papers (New York: Harcourt, Brace, 1920), pp. 167, 187.

9. Sanford Kadish, "The Model Penal Code's Historical Antecedents," Rutgers Law Jourmal 19 (1988): 521-38, at 521.

10. See American Law Institute, "Model Penal Code" (tentative draft no. $9,1959)$, pp. 56-57.

11. See Marzen et al., "Suicide," p. 95.

12. In re Quinlan, 70 N.J. 10,355 A.2d $647,665,670$ and fn. 9 (1976).

13. Norman Cantor, "The Permanently Unconscious Patient, Non-Feeding and Euthanasia," American Journal of Law and Medicine 15 (1989): 381-437, at 433.

14. Daniel Callahan, The Troubled Dream of Life: Living with Mortality (New York: Simon and Schuster, 1993), ch. 2.

15. Jeb Rubenfeld, "The Right to Privacy," Harvard Law Review 102 (1989): 737 807 , at 795.

16. Gruzan v. Director, Missouri Department of Health, 497 U.S. 261, 280 (1990). See also Paris Adult Theatre v. Slaton, 413 U.S. 49, 68 and fn. 15 (1973).

17. John Robertson, "Cruzan and the Constitutional Status of Nontreatment Decisions for Incompetent Patients," Geongia Law Review 25 (1991): 1139-1202, at 1174-75 and fn. 132.

18. See "The Supreme Court 1989 Term," Harvard Law Review 104 (1990): 43-358, at 257.
19. Louis Seidman, "Confusion at the Border: Cruzan, 'The Right to Die,' and the Public/Private Distinction," Supreme Court Review, 1992, pp. 47-76, at 62.

20. See "The Supreme Court 1989 Term," p. 262.

21. Smith, "All's Well That Ends Well," pp. 279-80. See also Mary Barrington, "Apologia for Suicide," in Euthanasia and the Right to Death: The Case for Voluntary Euthanasia, ed. A. B. Downing (Atlantic Highlands, N.J.: Humanities Press, 1969), p. 162 ("that voluntary euthanasia is in fact assisted suicide is no doubt clear to most people"); Raanon Gillon, "Suicide and Voluntary Euthanasia: Historical Perspectives," in Euthanasia and the Right to Death, pp. 173-74 ("voluntary euthanasia is essentially a form of suicide, involving the assistance of others").

22. See Joseph Fletcher, Morals and Medicine (Boston: Beacon Press, 1954), p. 176; James Rachels, The End of Life: Euthanasia and Morality (New York: Oxford University Press, 1986), pp. 86-87.

23. Quill, Death and Dignity, pp. 142 , 159 .

24. Brock, "Voluntary Active Euthanasia," p. 10. Brock is responding to Sidney Wanzer et al., "The Physician's Responsibility toward Hopelessly Ill Persons: A Second Look," NEJM 320 (1989): 844-49, at 848 . Although Wanzer and his coauthors stopped short of approving active voluntary euthanasia, they did not disapprove it.

25. These and subsequent quotations are from the transcript of "Choosing Death" (a special edition of Health Quarterly), 23 March 1993. The day the documentary was scheduled to be shown, it was described as a "debate about euthanasia." See Walter Goodman, "Euthanasia as It Seems to Those Taking Part," New York Times, 23 March 1993.

26. Robert Wennberg, Terminal Choices: Euthanasia, Suicide, and the Right to Die (Grand Rapids, Mich.: William B. Eerdmans, 1989), p. 99.

27. Alan Sullivan, "A Constitutional Right to Suicide," in Suicide: The Philosophical Issues, ed. Margaret P. Battin and David J. Mayo (New York: St. Martin's Press, 1980), p. 241.

28. Quill, Death and Dignity, p. 162.

29. Callahan, The Troubled Dream of Life, ch. 3. See also Leon Kass, "Neither for Love nor Money: Why Doctors Must Not Kill," The Public Interest 94 (1989): 25-46, at 32-33.

30. See Sullivan, "Constitutional Right to Suicide," p. 240.

31. See Alan Meisel, "Legal Myths about Terminating Life Support," Archives of Internal Medicine 109 (1991): 1497 1502, at 1498-99, discussing Bouvia, McAfee, and other cases. 
32. Blackmun, J., joined by Brennan, Marshall, and Stevens, JJ., dissenting in Bowers v. Hardwick, 478 U.S. 186, 199-200 (1986), and Stevens, J., joined by Brennan and Marshall, IJ., at 216. In Hardwick, a 5-4 majority upheld the constitutionality of a Georgia law criminalizing homosexual sodomy.

33. The quotations are from Morris $\mathbf{R}$. Cohen, The Faith of a Liberal (New York: Henry Holt, 1946), p. 70.

34. Sullivan, "Constitutional Right to Suicide," p. 243.

35. Philip Devine, The Ethics of Homicide (Ithaca: Cornell University Press, 1978), p. 188.

36. See George Colt, The Enigma of Suicide (New York: Summit Books, 1991), pp. 37-38; Herbert Hendin, Suicide in America (New York: W. W. Norton, 1982), pp. 185-86; David Clark, “'Rational' Suicide and People with Terminal Conditions or Disabilities," Issues in Law and Medicine 8 (1992): 147-66, at 148.

37. Hendin, Suicide in America, p. 214. See also Herbert Hendin and Gerald Kler- man, "Physician-Assisted Suicide: The Dangers of Legalization," American Journal of Psychiatry 150 (1993): 143-45.

38. Clark, "'Rational' Suicide," pp. 151-53.

39. Yeates Conwell and Eric Caine, "Rational Suicide and the Right to Die: Reality and Myth," NEJM 325 (1991): 1100-1102. See also James Brown et al., "Is It Normal for Terminally Ill Patients to Desire Death?" American Journal of Psychiatry 143 (1986): 208-11.

40. Conwell and Caine, "Rational Suicide and the Right to Die," p. 1101.

41. Quoted in Colt, The Enigma of Suicide, p. 342.

42. See Victor Rosenblum and Clark Forsythe, "The Right to Assisted Suicide: Protection of Autonomy or an Open Door to Social Killing?" Issues in Law and Medicine6 (1990): 3-31, at 27. See also Yale Kamisar, "Some Non-Religious Views Against Proposed 'Mercy-Killing' Legislation," Minnesota Law Review 42 (1958): 969-1042, at 990-93; David Velleman, "Against the Right to Die," Joumal of Med- icine and Philosophy 17 (1992): 664-81, at 664.

43. Margaret Pabst Battin, "Manipulated Suicide," in Suicide: The Philosophical Issues, pp. 169, 179.

44. Martin Marty and Ron Hamel, "Some Questions and Answers," in Active Euthanasia, Religion, and the Public Debate, ed. Ron Hamel (The Park Ridge Center, 1991), pp. 27, 40.

45. The quotations are from Albert Alschuler, "Reflection," in Active Euthanasia, pp. 105, 107, 108.

46. Laurence Tribe, American Constitutional Law, 2nd ed. (Mineola, N.Y.: Foundation Press, 1988), pp. 64-65. See also Yale Kamisar, "When Is There a Constitutional 'Right to Die'? When Is There No Constitutional 'Right to Live'? Georgia Law Review 25 (1991): 1203-42, at 1205-27.

47. Thomas Mayo, "Constitutionalizing the 'Right to Die," Maryland Law Review 49 (1990): 103-55, at 144. 